\title{
Praktikalitas Penggunaan Media Sosial Pembelajaran Edmodo untuk Program Remedial dan Forum Diskusi Guru
}

\author{
Zonalia Fitriza ${ }^{1)}$, Iswendi ${ }^{1)}$, Iryani ${ }^{1)}$, Faizah Qurratul 'Aini ${ }^{1)}$ \\ ${ }^{1)}$ Universitas Negeri Padang ${ }^{1)}$ \\ zonaliafitriza@gmail.com
}

\begin{abstract}
Remedial program is given to the students who do not pass the minimum criteria of learning result. Based on the "KTSP" Technical guidance evaluation in 2008 and 2009, generally teacher only gave retest to the student who didn't pass the examination, without giving any treatment to pass the learning outcome which was not pass before. It happened because there wasn't enough time to do this program. The solution was by using learning social media Edmodo which can be accessed online, so the students can do remedial program whenever and wherever they want without preparing remedial time at school. So, the Chemistry teachers in Kabupaten Solok was trained to use edmodo for remedial program. Besides, this media was also used for online teacher forum. This training was evaluated through questioner about practicality of social media edmodo for remedial program and online teacher forum. The result was analyzed by Kappa Cohen Formula with the value of $k$ is 0,7, it means has high practice value.
\end{abstract}

Keywords : Edmodo, Online teacher Forum, Practicality, Remedial

his is an open access article distributed under the Creative Commons 4.0 Attribution License, which permits unrestricted use, distribution, and reproduction in any medium, provided the original work is properly cited $\odot 2018$ by author and Universitas Negeri Padang.

\section{PENDAHULUAN}

Menurut Direktorat Pembinaan SMA (2010) belajar tuntas (mastery learning) merupakan pendekatan dalam pembelajaran yang mempersyaratkan peserta didik menguasai secara tuntas seluruh standar kompetensi maupun kompetensi dasar mata pelajaran tertentu. Hal ini juga didukung pernyataan dalam lampiran IV Peraturan Menteri Pendidikan dan Kebudayaan Republik Indonesia Nomor 81A tahun 2013 tentang implementasi kurikulum bahwa untuk kompetensi pada kategori pengetahuan dan keterampilan (KI-3 dan KI-4), peserta didik tidak diperkenankan mengerjakan pekerjaan berikutnya sebelum mampu menyelesaikan pekerjaan dengan prosedur yang benar dan hasil yang baik. Selain itu dijelaskan juga bahwa dalam belajar tuntas diasumsikan bahwa peserta didik dapat mencapai kompetensi yang sama namun dalam waktu yang berbeda-beda. Peserta didik dengan kemampuan rendah perlu waktu lebih lama untuk materi yang sama dibandingkan peserta didik yang mempunyai kemampuan tinggi

Selesai atau tidaknya siswa menguasai kompetensi yang diinginkan terukur dari Kriteria Ketuntasan Minimum (KKM). Jika nilai siswa sama atau melebihi ketuntasan minimum maka siswa tersebut dinyatakan tuntas, sebaliknya jika nilai siswa dibawah ketuntasan minimum yang telah ditetapkan maka siswa dinyatakan tidak tuntas. Untuk kompetensi yang belum tuntas maka dapat diselesaikan dengan program remedial yang merupakan tindak lanjut dari penilaian. Hal ini didukung oleh pernyataan Afriyani (2013) bahwa setelah melakukan penilaian, guru bisa memberikan tindak lanjut berupa program perbaikan (remedial) bagi siswa yang tidak mencapai tujuan pembelajaran atau program pengayaan untuk siswa yang telah mencapai tujuan pembelajaran. Kedua program ini sangat diperlukan dalam rangka pelaksanaan pola belajar yang tuntas. Terkait remedial, program ini dilakukan dengan metode pem berian tugas, metode diskusi, metode Tanya jawab, metode kerja kelompok, metode tutor sebaya dan pengajaran individual. Sedangkan untuk program pengayaan siswa memperoleh pengetahuan dengan cara belajar kelompok, belajar mandiri, pembelajaran berbasis tema dan pemadatan kurikulum (lampiran IV Peraturan Menteri Pendidikan dan Kebudayaan Republik Indonesia Nomor 81A tahun 2013 tentang implementasi kurikulum).

Penjelasan di atas mengindikasikan bahwa program remedial merupakan program yang harus dilakukan dalam kurikulum 2013 dalam 
pelaksanaan pembelajaran tuntas. Namun kenyataannya tidak semua guru melaksanakan kegiatan tersebut. Berdasarkan hasil evaluasi kegiatan bimtek KTSP tahun 2008 dan 2009 yang dilaksanakan oleh Direktorat Pembinaan SMA ditemukan bahwa pada umumnya pen didik melakukan tes ulang terhadap peserta didik yang remedial tanpa melakukan perbaikan proses pembelajaran berdasarkan analisis hasil belajar siswa. Perbaikan sering tidak dilakukan karena tidak terjadwalnya kegiatan ini dan dilaksanakan di luar jam pelajaran.

Permasalahan yang dihadapi guru-guru Kimia SMA Kabupaten Solok yang dibuktikan dengan surat permintaan pengadaan pelatihan program remedial membuktikan hasil evaluasi kegitan Bimtek KTSP tahun 2008/2009 yang menyatakan bahwa umumnya guru hanya melaksanakan tes ulang tanpa melakukan kegiatan remedial terlebih dahulu. Hal ini dikarenakan tidak cukupnya waktu melaksana kan kegiatan tersebut. Maka, dilaksanaan remedial dengan menggunakan edmodo yang dapat memberikan efektifitas lebih besar di bandingkan cara konvensional dibuktikan dengan rata-rata persentase kenaikan hasil tes ulang yang lebih besar dibandingkan cara konvensional (Fitriza: 2016).

Keunggulan edmodo dalam mendukung kegiatan remedial adalah bisa memediasi komunikasi guru dan siswa dalam program remedial secara virtual. Edmodo adalah suatu platform pembelajaran gratis dan aman yang didesain oleh Jeff O'Hara dan Nick Borg pada tahun 2008 untuk guru, siswa, orang tua dan sekolah (Kongcham, 2013). Situs ini gratis karena dapat diakses sebagaimana facebook, tweeter dan media sosial lainnya dan dikatakan sebagai platform pembelajaran yang aman karena hanya dapat diakses dengan mengguna kan kode grup sehingga tidak memungkinkan orang-orang tidak bertanggung jawab ikut serta dalam kegiatan digrup tersebut. Hal ini didukung oleh pernyataan Monalisa dan Havid Ardi (2013) bahwa edmodo sangat aman dari spam dan content yang tidak baik, karena guru bisa melihat semua yang di posting pada edmodo dan orang tua bisa bergabung dengan edmodo untuk melihat semua yang dikerjakan anaknya dan bagaimana perkembangan belajar mereka.

Tampilan dan penggunaan edmodo sangat mirip dengan facebook sehingga sangat familiar baik bagi guru, siswa dan orang tua. Fitur yang disediakanpun sangat mendukung pembelajaran khususnya program remedial dan pengayaan, karena dengan media sosial ini, guru bisa menyediakan sumber-sumber belajar, ber diskusi, berkomunikasi melalui fitur "Chat" dan siswa bisa mengakses dan juga berbagi sumber pengetahuan dengan siswa lain. Selain itu, edmodo memiliki fitur yang bisa mendukung kebutuhan akademik untuk penilaian seperti quiz, tugas dan polling. Hal ini didukung oleh pernyataan Balasubranian dkk (2014) bahwa edmodo adalah bentuk media sosial yang biasa disebut sebagai "facebook" untuk pendidikan, karena tampakan edmodo yang mirip dengan facebook untuk menunjukan bahwa edmodo mudah digunakan sebagaimana facebook.

Perbedaan antara edmodo dengan situs sosial media lain adalah adanya platform pembelajaran yang memungkinkan untuk siswa, guru dan orang tua berkolaborasi, ber komunikasi, berbagi pengetahuan, mengakses tugas dan nilai. Selain itu, sebuah hasil penelitian menyatakan bahwa semua partisipan menyatakan sikap positif mengenai aplikasi pemberian tugas melalui edmodo dan aplikasi polling serta pemberitahuan/ berbagi fitur edmodo merupakan yang paling disukai oleh partisipan (Cankaya, 2013). Lebih lanjut Cankaya menjelaskan bahwa mayoritas partisipan mempunyai pendapat yang sama mengenai kontribusi edmodo untuk pem belajaran seperti membuat pembelajaran menyenangkan, menarik perhatian siswa, mempermudah kerja guru, membuat pelajaran efektif dan terorganisir dan cocok untuk siswa dimasa yang akan datang. Pernyataan ini mengindikasikan bahwa edmodo disukai oleh siswa, dapat membantu guru dalam pem belajaran dan media ini cocok untuk siswa, guru dan sekolah yang terbuka dengan penggunaan teknologi dalam pembelajaran

Selain bisa digunakan untuk program remedial, media sosial edmodo bisa dijadikan sebagai suatu media oleh guru dalam suatu forum guru dimana guru bisa saling berdiskusi dan berbagi pengalaman mengenai materi kimia, pembelajaran berupa metode, media dan strategi pembelajaran untuk topik-topik kimia. Carboni (1999) menginvestigasi penggunaan forum diskusi online untuk mendukung pelaksanaan pembelajaran guru. Forum tersebut dibangun dengan berbagi informasi, dikusi dan merefleksi kan pengajaran. Forum membantu guru dalam membuat kesan baik dalam pembelajaran. 
Pelaksanaan program remedial melalui edmodo dilakukan dengan membuat akun guru terlebih dahulu dengan registrasi melalui www.edmodo.com. Setelah memiliki akun, guru bisa membuat kelompok-kelompok kelas dan tiap kelas tersebut mempunyai kode grup masing-masing sehingga pelaksanaan program ini dilaksanakan secara aman karena hanya orang-orang yang memiliki kode grup saja yang bisa mengakses pembelajaran. Artinya siswa hanya bisa mengakses pembelajaran pada kelasnya saja dan tidak akan mendapat gangguan dari orang-orang tidak bertanggung jawab yang biasa ditemui di media sosial lain.

Setelah mendapat kode grup, siswa melakukan registrasi dan memasukkan kode tersebut sehingga bisa bergabung pada kelas yang telah dibuat guru pada edmodo. Siswa bisa mengakses semua sumber pembelajaran dan tugas, melakukan quiz, berdiskusi dan berkomunikasi via chat kapan saja dan dimana saja dengan cara yang sama dengan media sosial facebook. Dengan demikian waktu yang minim untuk pelaksanaan remedial disekolah bisa diatasi dengan pembelajaran melalui internet.

Walaupun banyak keuntungan yang dapat diperoleh dari penggunaan edmodo, bedasarkan penelitian terdapat beberapa kelemahan edmodo yaitu sebagai berikut ini.

1. Keterbatasan interaksi dalam edmodo Artinya siswa bisa berinteraksi dengan guru namun tidak bisa berinteraksi dengan siswa lain.

2. Beberapa aplikasi tidak bisa digunakan melalui handphone.

Salah satunya adalah tidak bisa mengirim tugas melalui handphone.

(Cankaya ; 2013)

Kelemahan-kelemahan yang dimiliki edmodo menyebabkan edmodo disarankan hanya sebagai alat tambahan disekolah, bukan untuk menggantikan pembelajaran utama di sekolah. Artinya pembelajaran utama dilaksana kan disekolah, sedangkan edmodo dapat diguna kan sebagai media tambahan untuk pem belajaran. Salah satunya adalah untuk remedial dan pengayaan, karena pelaksanaan kedua program tersebut harus dilakukan diluar jam pelajaran.

\section{METODE PENELITIAN}

Kegiatan ini dilakukan untuk menentukan praktikalitas penggunaan media sosial Edmodo untuk program remedial dan Forum Diskusi Guru melalui pemberian pelatihan kepada Guruguru kimia yang tegabung dalam Musyawarah Guru Mata Pelajaran Kimia kota Solok Sumatera Barat.

Pelaksanaan kegiatan dilakukan dalam 3 tahapan yaitu :

1. Tahap Persiapan

Tahap persiapan ini adalah rangkaian kegiatan sebelum dilaksanakannya pelatihan berupa:

a. Pembentukan Tim yang akan membantu dikarenakan kebutuhan tenaga dalam memandu guru-guru kimia dalam pelatihan yang melibatkan komputer dan internet. Supaya lebih efektif, perbandingan tim dengan guru adalah 1 $: 10$.

b. Diskusi dengan Ketua MGMP Kimia Kabupaten Solok terkait tempat pelaksanaan, sarana yang dibutuhkan dan persiapan guru sebelum pelaksanaan kegiatan

c. Pelatihan Tim untuk memastikan keterampilan tim dalam menggunakan media sosial edmodo.

d. Persiapan alat-alat dan kebutuhan lain yang diperlukan dalam pelaksanaan kegiatan seperti Media Presentasi untuk materi Program Remedial, Media Sosial Edmodo dan Forum Diskusi Guru.

2. Tahap Pelaksanaa

Tahap palaksanaan adalah tahapan kegiatan saat pelatihan berlangsung. Pelaksanaan dilaksanakan sebanyak dua kali pertemuan yaitu:

a. Pertemuan I

Pada pertemuan pertama dilaksanakan pelatihan pembuatan media sosial edmodo untuk satu materi kimia, mulai dari pembuatan akun, penyiapan bahan pembelajaran, melengkapi pemberian tugas, kuis dan polling

b. Pertemuan II

Pada pertemuan kedua dilaksanaan diskusi mengenai rancangan program remedial yang dibuat guru untuk kemudian dilaksanakan pada masingmasing sekolah. Pada pertemuan kedua juga diberikan pelatihan membuat akun dan menggunakan media sosial Edmodo untuk kegiatan Forum Diskusi Guru untuk digunakan untuk keperluan Musyawarah Guru Mata Pelajaran. 
3. Tahap Evaluasi

Tahapan evaluasi dilaksanakan 2 tahap. Tahap pertama adalah pada pertemuan ke dua dengan mengadakan diskusi hasil pelatihan pada pertemuan pertama dan pemberian angket pemahaman dan kepuasan mitra.

Secara ringkas tahapan pelaksanaan kegiatan dapat dilihat pada Gambar 1 berikut,

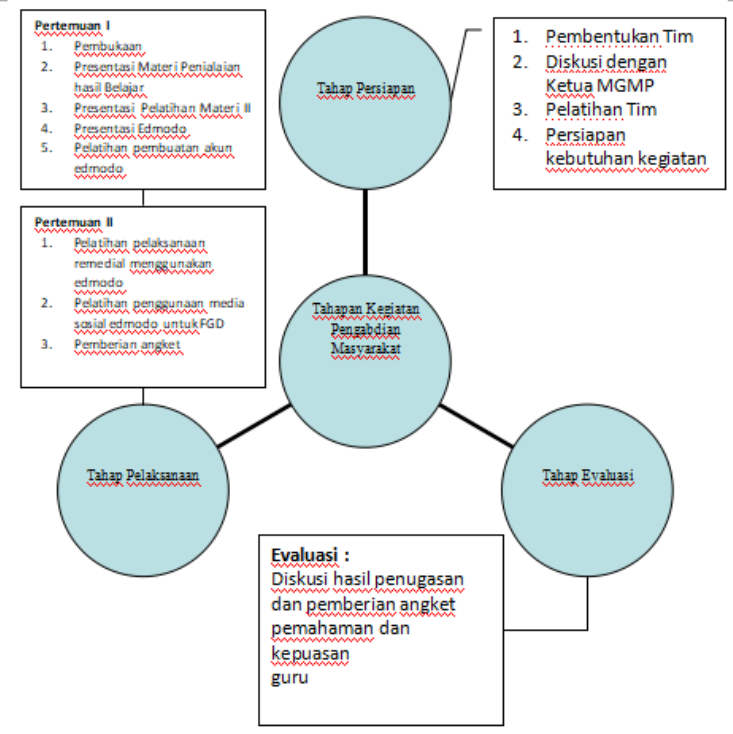

Gambar 1. Tahapan Pelaksanaan Pelatihan Penggunaan Media Sosial Edmodo untuk Program Remedial an Forum Diskusi Guru

4. Analisis data

Analisis data yang dilakukan adalah dengan menggunakan formula kappa cohen untuk menguji praktikalitas penggunaan media sosial edmodo untuk program remedial dan forum diskusi guru. Formula tersebut adalah sebagai berikut.

$$
\text { moment kappa }(\mathrm{k})=\frac{P o-P e}{1-P e}
$$

Po adalah proporsi yang terealisasi, dihitung dengan cara:

\section{Po $=\underline{\text { Jumlah nilai yang diberikan }}$ Jumlah nilai maksimum}

$P e$ adalah proporsi yang tidak terealisasi, dihitung dengan cara:

$\mathrm{Pe}=$ jumlah nilai maksimal-jumlah niai yang diberi Jumlah nilai maksimal

Momen Kappa (k) berkisar dari 0 sampai 1, dengan interpretasi menurut Boslaugh \& Watters (2008) disajikan pada Tabel 1.
Tabel 1. Interpretasi Nilai Momen Kappa (k) menurut Boslaugh \& Watters

\begin{tabular}{|c|c|}
\hline Nilai $\mathrm{k}$ & Kategori \\
\hline $0,81-1,00$ & Sangat Tinggi \\
\hline $0,61-0,80$ & Tinggi \\
\hline $0,41-0,60$ & Sedang \\
\hline $0,21-0,40$ & Rendah \\
\hline $0,00-0,20$ & Sangat Rendah \\
\hline$<0,00$ & Tidak diperhitungkan \\
\hline
\end{tabular}

\section{HASIL DAN PEMBAHASAN}

Penggunaan Media Sosial Edmodo pada saat pelatihan adalah dengan membuat akun, mengirim dan menerima pesan, komentar, tugas, kuis, video, link, dan berdiskusi. Pada kegiatan ini, guru-guru yang tergabung dalam Musyawarah Guru Mata Pelajaran membuat akun edmodo dan dilanjutkan dengan mem persiapkan bahan-bahan pembelajaran seperti Media Power Point, animasi, Lembar Kerja Siswa, penugasan, kuis dan polling untuk satu materi pelajaran kimia. Kegiatan tersebut dapat dilihat pada Gambar 2.

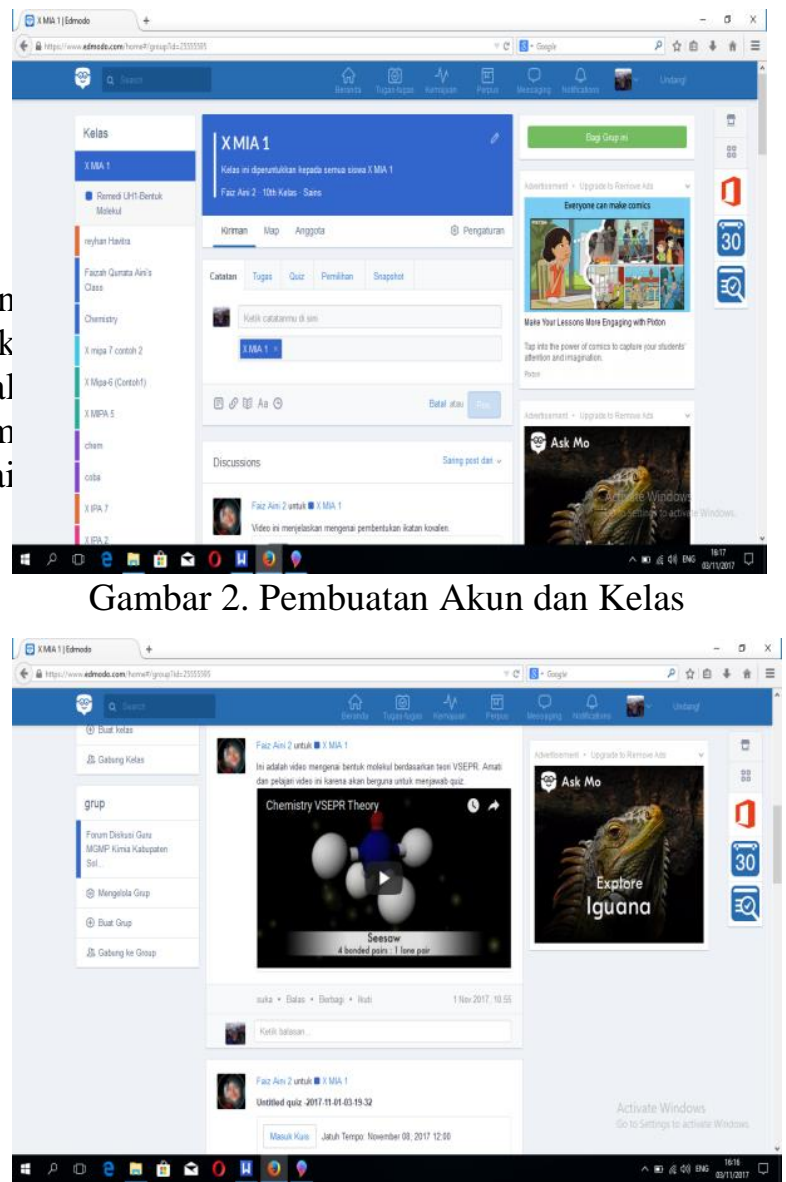

Gambar 3. Pengiriman Video dan Link 


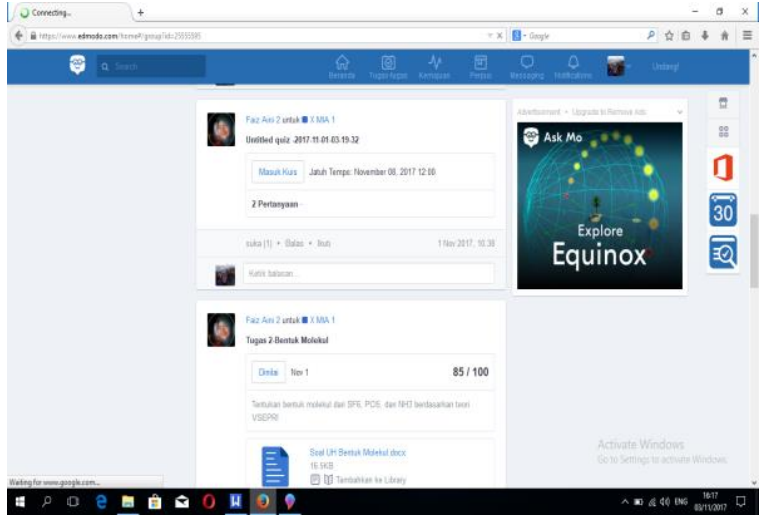

Gambar 4. Pengiriman Kuis

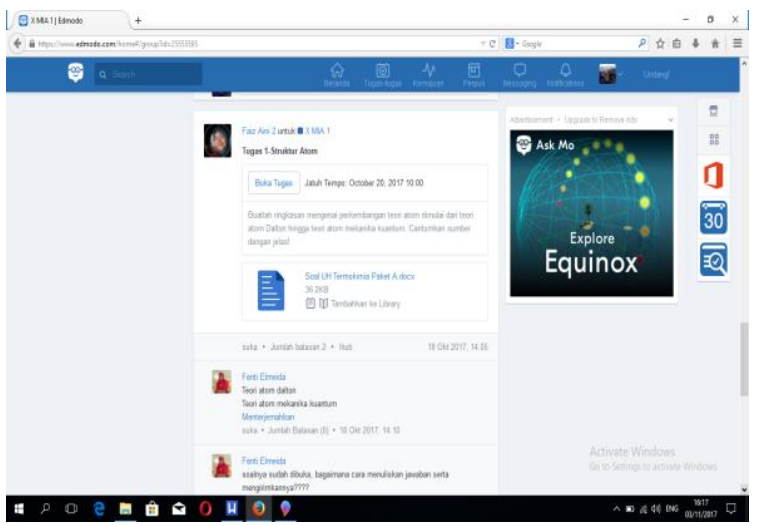

Gambar 5. Pengiriman Tugas

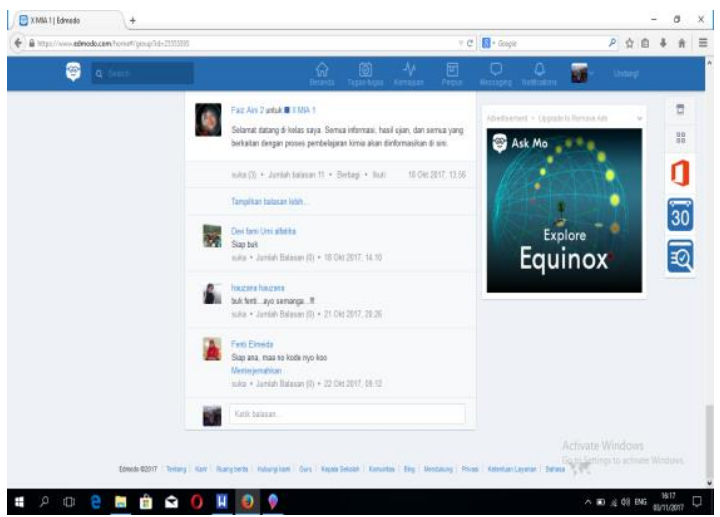

Gambar 6. Komentar

Kepraktisan penggunaan media sosial edmodo oleh guru-guru MGMP kota Solok Sumatera Barat dilihat dengan menggunakan instrumen angket. Instrumen tersebut terdiri dari 22 peryataan yang terbagi kedalam aspek kemudahan penggunaan edmodo, aspek manfaat edmodo untuk program remedial dan aspek penggunaan edmodo untuk forum diskusi guru.

Hasil yang diperoleh untuk kemudahan penggunaan dapat dilihat pada Tabel 2.
Tabel 2. Kepraktisan Aspek Kemudahan Penggunaan Edmodo

\begin{tabular}{|c|l|c|c|}
\hline $\begin{array}{l}\mathrm{N} \\
\mathrm{o}\end{array}$ & Pernyataan & $\mathrm{K}$ & interpretasi \\
\hline 1 & $\begin{array}{l}\text { Edmodo dapat digunakan } \\
\text { dimana saja }\end{array}$ & 0.63 & Tinggi \\
\hline 2 & $\begin{array}{l}\text { Edomodo dapat } \\
\text { digunakan kapan saja }\end{array}$ & 0.63 & Tinggi \\
\hline 3 & $\begin{array}{l}\text { Edmodo dapat digunakan } \\
\text { berulang-ulang }\end{array}$ & 0.79 & Tinggi \\
\hline 4 & $\begin{array}{l}\text { Edmodo mudah } \\
\text { digunakan guru untuk } \\
\text { mengirim berkas, gambar, } \\
\text { video, dan link }\end{array}$ & 0.87 & $\begin{array}{l}\text { Sangat } \\
\text { Tinggi }\end{array}$ \\
\hline & Kepraktisan penggunaan & 0,74 & Tinggi \\
\hline
\end{tabular}

Berdasarkan Tabel 2 diketahui bahwa kepraktisan kemudahan penggunaan edmodo berada pada kategori tinggi dimana edmodo dapat digunakan dimana saja, kapan saja, dapat digunakan berulang-ulang dan dapat digunakan untuk mengirim berkas gambar, video, link dan lain-lain.

Kepraktisan penggunaan media sosial edmodo untuk program remedial dan forum diskusi guru dari aspek manfaat dapat dilihat pada Tabel 3 dan 4.

Tabel 3. Kepraktisan Berdasarkan Aspek Manfaat Edmodo untuk Forum Diskusi Guru

\begin{tabular}{|l|l|l|c|}
\hline $\begin{array}{l}\mathrm{N} \\
\mathrm{o}\end{array}$ & Pernyataan & $\mathrm{k}$ & Interpretasi \\
\hline 1 & $\begin{array}{l}\text { Edmodo memudahkan } \\
\text { komunikasi antara guru }\end{array}$ & 0.78 & Tinggi \\
\hline 2 & $\begin{array}{l}\text { Guru dapat menggunakan } \\
\text { edmodo untuk } \\
\text { mengembangkan ruang } \\
\text { diskusi dimana guru dapat } \\
\text { berkomunikasi satu } \\
\text { dengan yang lainnya di } \\
\text { waktu yang sama }\end{array}$ & 0.76 & Tinggi \\
\hline 3 & $\begin{array}{l}\text { Edomodo dapat dijadikan } \\
\text { alternatif pengganti } \\
\text { kegiatan Musyawarah } \\
\text { Guru Mata Pelajaran } \\
\text { (MGMP) tanpa tatap } \\
\text { muka langsung }\end{array}$ & 0.72 & Tinggi \\
\hline 4 & $\begin{array}{l}\text { Edmodo dapat digunakan } \\
\text { guru untuk mengirim } \\
\text { berkas, gambar, video, } \\
\text { dan link yang relevan } \\
\text { dengan topik forum } \\
\text { diskusi guru dengan } \\
\text { mudah }\end{array}$ & 0.81 & $\begin{array}{l}\text { Sangat } \\
\text { Tinggi } \\
\text { guru untuk mengunduh }\end{array}$ \\
\hline 5 & 0.79 & Tinggi \\
\hline
\end{tabular}




\begin{tabular}{|l|l|c|c|}
\hline & $\begin{array}{l}\text { berkas, gambar, video, } \\
\text { dan link yang dibagikan } \\
\text { pada grup forum diskusi } \\
\text { guru }\end{array}$ & & \\
\hline 6 & $\begin{array}{l}\text { Edmodo membantu guru } \\
\text { dalam membuat berita di } \\
\text { grup forum diskusi guru }\end{array}$ & 0.79 & Tinggi \\
\hline 7 & $\begin{array}{l}\text { Edmodo menjadikan } \\
\text { waktu untuk berdiskusi } \\
\text { menjadi lebih efisien }\end{array}$ & 0.79 & Tinggi \\
\hline & Kepraktisan & 0.78 & Tinggi \\
\hline
\end{tabular}

Berdasarkan Tabel 3 diketahui bahwa respon guru terhadap manfaat media sosial edmodo untuk forum diskusi guru baik dengan nilai momen kappa (k) adalah 0,78 yang diinterpretasi memiliki kepraktisan tinggi.

Demikian juga yang terjadi pada respon guru terhadap kepraktisan penggunaan media sosial edmodo untuk forum diskusi guru yaitu dengan momen kappa 0,7. Nilai ini diinterpretasi memiliki kepraktisan tinggi. Secara rinci dapat dilihat pada tabel 3 .

Tabel 5. Kepraktisan berdasarkan aspek manfaat edmodo untuk Program remedial

\begin{tabular}{|c|c|c|c|}
\hline No & Pernyataan & $\mathrm{K}$ & Interpretasi \\
\hline 1 & $\begin{array}{l}\text { Edmodo } \\
\text { mendukung peran } \\
\text { guru sebagai } \\
\text { fasilitator }\end{array}$ & 0.72 & Tinggi \\
\hline 2 & $\begin{array}{l}\text { Edmodo } \\
\text { memudahkan } \\
\text { komunikasi antara } \\
\text { guru dan siswa }\end{array}$ & 0.69 & Tinggi \\
\hline 3 & $\begin{array}{l}\text { Edmodo dapat } \\
\text { dijadikan alternatif } \\
\text { pengganti kegiatan } \\
\text { remedial di sekolah }\end{array}$ & 0.69 & Tinggi \\
\hline 4 & $\begin{array}{l}\text { Edmodo dapat } \\
\text { digunakan guru } \\
\text { untuk membuat } \\
\text { berita remedial } \\
\text { dalam grup } \\
\end{array}$ & 0.71 & Tinggi \\
\hline 5 & $\begin{array}{l}\text { Guru dapat } \\
\text { menggunakan } \\
\text { edmodo untuk } \\
\text { menginstruksikan } \\
\text { tugas remedial } \\
\text { dengan siswanya } \\
\text { secara online }\end{array}$ & 0.74 & Tinggi \\
\hline 6 & $\begin{array}{l}\text { Edmodo dapat } \\
\text { digunakan guru } \\
\text { untuk mengirim } \\
\text { berkas, gambar, } \\
\text { video, dan link yang }\end{array}$ & 0.76 & Tinggi \\
\hline
\end{tabular}

\begin{tabular}{|l|l|l|l|}
\hline & $\begin{array}{l}\text { berkaitan dengan } \\
\text { remedial siswa }\end{array}$ & & \\
\hline 7 & $\begin{array}{l}\text { Guru dan siswa } \\
\text { dapat mengunduh } \\
\text { berkas, gambar, } \\
\text { video, dan link yang } \\
\text { relevan dengan } \\
\text { materi terkait } \\
\text { dengan mudah }\end{array}$ & 0.74 & Tinggi \\
\hline 8 & $\begin{array}{l}\text { Guru dan siswa } \\
\text { dapat bertukar } \\
\text { sumber melalui } \\
\text { edmodo, baik antara } \\
\text { guru dan siswa, } \\
\text { maupun antara } \\
\text { siswa dan siswa }\end{array}$ & 0.67 & Tinggi \\
\hline 9 & $\begin{array}{l}\text { Edmodo dapat } \\
\text { digunakan guru } \\
\text { untuk menerima } \\
\text { tugas yang telah } \\
\text { diinstruksikan pada } \\
\text { siswa dengan } \\
\text { mudah }\end{array}$ & 0.69 & Tinggi \\
\hline 10 & $\begin{array}{l}\text { Edmodo } \\
\text { memudahkan guru } \\
\text { untuk memberikan } \\
\text { soal Quiz tanpa } \\
\text { perlu tatap muka } \\
\text { langsung }\end{array}$ & 0.72 & Tinggi \\
\hline 11 & $\begin{array}{l}\text { Edmodo dapat } \\
\text { digunakan guru } \\
\text { untuk memberikan } \\
\text { nilai pada siswa } \\
\text { secara manual } \\
\text { maupun otomatis }\end{array}$ & 0.71 & Tinggi \\
\hline 12 & $\begin{array}{l}\text { Edmodo dapat } \\
\text { meningkatkan minat } \\
\text { siswa dalam } \\
\text { mengerjakan } \\
\text { remedial }\end{array}$ & 0.63 & Tinggi \\
\hline 13 & $\begin{array}{l}\text { Edmodo } \\
\text { menjadikan waktu } \\
\text { remedial menjadi } \\
\text { lebih efisien }\end{array}$ & 0.69 & Tinggi \\
\hline $\begin{array}{l}\text { Kepraktisan } \\
\text { Tinagi }\end{array}$ & 0.70 & Tinggi \\
\hline
\end{tabular}

Hasil pada Tabel 1,2 dan 3 sejalan dengan peryataan Balasubranian dkk (2014) bahwa edmodo adalah bentuk sosial media yang biasa disebut sebagai "facebook" untuk pendidikan, karena tampakan edmodo yang mirip dengan facebook untuk menunjukan bahwa edmodo mudah digunakan sebagaimana facebook. Perbedaan antara edmodo dengan situs sosial media lain adalah adanya platform pembelajaran yang memungkinkan untuk siswa, guru dan 
orang tua berkolaborasi, berkomunikasi, berbagi pengetahuan, mengakses tugas dan nilai.

Penggunaan media sosial edmodo untuk forum diskusi guru direspon positif oleh guru dimana dengan adanya forum diskusi guru melalui edmodo mempermudah komunikasi antar guru baik itu dalam berdiskusi, saling bertukar informasi dan sumber belajar serta menjadi alternatif penambah pertemuan MGMP tanpa tatap muka.

Manfaat edmodo untuk program remedial dinilai baik oleh guru dimana guru bisa menjadi fasilitator pembelajaran melalui edmodo, guru dan siswa bisa berbagi informasi dan sumber belajar, guru bisa memberi penugasan dan kuis serta langsung bisa mengevaluasi hasil belajar. Berkaitan dengan ini, Fitriza (2017) menyimpulkan bahwa hasil tes ulang siswa setelah program remedial melalui edmodo lebih baik dibandingkan hasil tes ulang siswa setelah program remedial dengan cara konvensional.

\section{KESIMPULAN}

Berdasarkan pembahasan tersebut dapat disimpulkan bahwa penggunaan media sosial edmodo untuk program remedial dan forum diskusi guru memiliki kepraktisan yang tinggi baik dari segi kegunaan penggunaan maupun dari segi manfaat.

\section{DAFTAR PUSTAKA}

Balasubramaniana, Kandappan, Jaykumar, Vb, et all. (2014). A study on "Student preference towards the use of Edmodo as a learning platform to create responsible learning environment" Procedia - Social and Behavioral Sciences 144 (2014) 416-422, 5th Asia Euro Conference 2014

Boslaugh, Sarah dan Paul A. W. (2008). Statistics in a Nutshell, a desktop quick reference. O'reilly: Beijing, Cambridge, Famham, Köln, Sebastopol, Taipei,Tokyo
Cankaya. (2013). Using Educational Social Networking Sites in Higher Education: Edmodo through the Lenses of Undergraduate Students. European Journal of Educational Technology. Volume: 1 Issue: 1 Autumn 2013

Carboni, L. W. (1999). How might an online discussion forum support teachers' professional development in mathematics?ERIC Document Reproduction Service No. ED444853

Direktorat Pembinaan SMA. (2010), Juknis Pembelajaran Tuntas, Remedial, Dan Pengayaan Di SMA".

Fitriza, Zonalia, Fauzana Gazali. (2016). "Efektifitas Penggunaan Media Sosial Pembelajaran Edmodo Untuk Program Remidial Pada Mata Pelajaran Kimia Semester 1 Kelas X SMA", Laporan Penelitiaan, Universitas Negeri Padang (2017). The Effectivity of Using Learning Social Media Edmodo for Remedial Program in The Topic Chemical Nomenclature. Proceeding The Annual International Seminar on Trends in Science and Science Education, Universitas Negeri Medan

Kongcham. Chada (2013). "How Edmodo and Google Docs can change classrooms", The European Conference on Language Learning 2013, Brighton, United Kingdom, paper\#0442.

Monalisa, Havid Ardi. (2013). Using edmodoeducational sosial network in teaching English for high school students, Jurnal of English Language Taching vol. 2 No. 1 , September 2013, serie c.

Kementerian Pendidikan dan Kebudayaan. (2013). Lampiran IV Peraturan Menteri Pendidikan dan Kebudayaan Republik Indonesia Nomor 81A tahun 2013 tentang implementasi kurikulum. Kemendikbud RI 